\title{
MANJU SHREE DEGAH: A RESTORATION
}

\author{
Sajeev Shakya ${ }^{1}$, Manjushree Shakya ${ }^{2}$, \\ ${ }^{1}$ Structure Engineer \\ Email Address:sajeevshakya@yahoo.com \\ ${ }^{2}$ Architect, C.E.O Techno Arch Nepal P. Ltd. \\ Email Address: technoarchnepal@gmail.com
}

\begin{abstract}
This article deals with the history, case study of one of the historically important ancient temple architecture of Kathmandu Valley. This also addresses the transformation through times and its restoration.
\end{abstract}

Key Words: Pegoda, Degah, Stupa

\section{Introduction}

Nepal is an Asian country that lies in the lap of the Great Himalayas. It is land of scenic beauty, magnificent mountain ranges, amazing flora and fauna, diverse culture, culturally rich elegant palaces and enormous number of temples. There are many historically important monuments and temples in Nepal in Kathmandu valley, the capital city of Nepal.

Architecture of temples seen in Kathmandu valley has its own importance with different styles. They are:
- Pagoda,
- $\quad$ Shikhara,
- $\quad$ Stupa and Chaitya
- Bahals/Viharas.

Pagoda Temples: Pagoda is a mandala in three-dimensional form, its square base sheltering the garbhagriha or "womb house" of the deity inside. Pagodas are masterpieces of majesty and balance, reaching up to the heavens like mountain peaks connecting earth and sky.

Shikara: Shikara means "mountain peak", and this soaring stone or brick temple is designed to replicate the towering peaks of the Himalaya.

Stupa and Chaitya: Exclusively Buddhist monuments, stupas are hemispherical half-domes, sanctified by sacred relics enshrined inside.

Bahal: These sprawling multistoried residential structures set around a central courtyard are scattered through the main cities of the Valley. The Bahal (also called vihara) began in the 7th century as a monastery for Buddhist monks and a center of religious learning and art.

Among these styles, Manju Shree Degah (Manju Shree Temple) in Manju Shree Tole or Majipat or Manjupatan, is the oldest Pagoda style temple. According to mythological history, Majipat was the first settlement area of mankind in the Kathmandu valley and established by the first king of valley, Dharmakar. 


\section{History and its importance}

The exact date of construction of the existing two roof pagoda style temple of Manju Shree is not known since inscriptions are missing. But as per the history, Manjupatan (currently Majipat) is the place in Kathmandu valley where people first started living. According to the mythology, Lord Manju Shree came from Lhasa to pay homage to Swoyambhu Nath Stupa (self-appearing Buddha) when the Kathmandu Valley was still a lake. When Lord Manju Shree reached the top of the Maha-mandapgiri, current-day Nagarkot, he saw the beautiful landscape of the Kathmandu Valley and thought that, if the water could be released from the lake, the valley would be a beautiful habitable place to live in. Lord Manju Shree went to the current-day area Chovar and made an opening with his sword thereby releasing water from the lake.

After draining the water, Lord Manju Shree built a city called Manjupatan. He crowned his follower Dharmakar, the ruler of the Manjupatan. Thereafter, he taught the people different crafts, arts, music and dances to make Manjupatan a prosperous city.

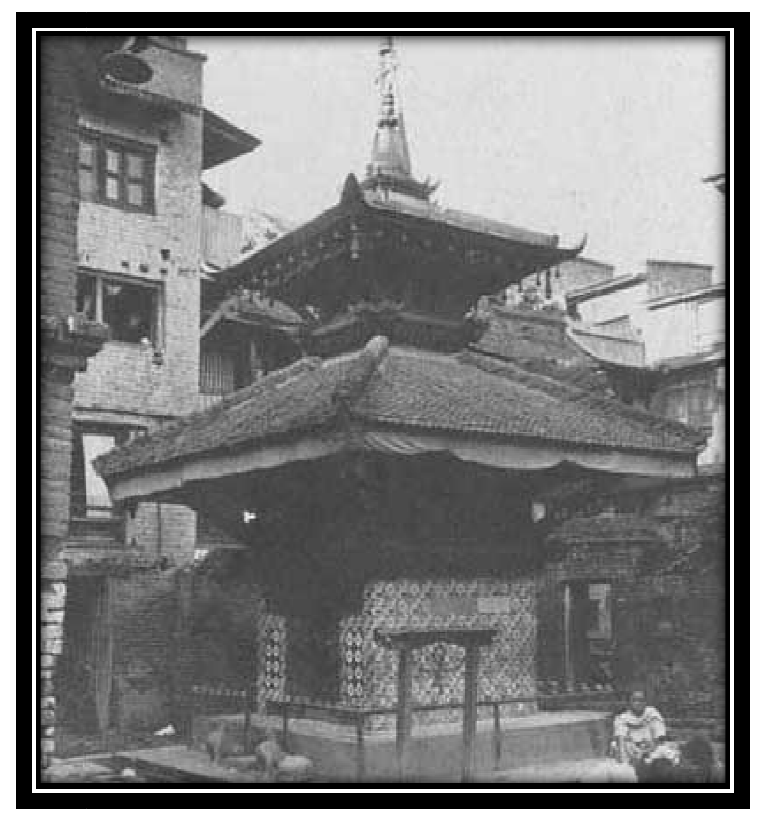

Fig 1 Manju Shree Degah after 1990 B.S earthquake

According to some mythological history told by ancestors, "King Dharmakar worship Lord Manjushree as his "Kul Deity" (Family Deity) and goddess Vajrayogini as his "Ista Deity"(the god to which one prays most). King Dharmakar used to go to Sankhu every early morning to feed and worship his "Ista Devotee" goddess Vajrayogini. At the time of Dharmakar rule, King Ugrasen from India visited Kathmandu to find the reason behind Dharmakars'every day visit to Sankhu. Following the Dharmakar, he found the reason behind his visit. Then once he went to Sankhu earlier than Dharmakar and fed Vajrayogini. Receiving a differently delicious meal that day, deity became very happy and gifted Ugrasen with a "Chudamani", a precious jem. She happily urges him not to visit the place onward to feed her. Dharmakar being unknown to the fact, as usual visited Vajrayogini. But, since the goddess was already fed, and also asked by goddess not to visit her again from that day, he had to return his palace without worshipping and feeding.

Dharmakar, not being able to worship Vajrayogini at Sankhu, established a temple for Vajrayogini or Ugratara at Chikanmuga (a place near Majipat). He also established temple for the "Kul Deity" Manju Shree as Manju Shree temple at Manjushree Bahal, Majipat. So, the Place where he ruled was put after the name of these two deities as "IKU Bahal"(I from Ista and $\mathrm{Ku}$ from Kul). So there is a history behind how the IkuBahal was named. 
It is said that this Manju Shree degah was the first to worship Lord Manju Shree made by Dharmakar.

\section{Case study:}

Case study was carried out after the earthquake of $25 \mathrm{t}^{\mathrm{h}}$ April 2015 in Nepal for its restoration and after its restoration.

\section{Architecture of degah}

\section{- Measured drawings}

It is two-tiered temple with square base. Wall is 18 " thick with brick and mud mortar that rests on 7'4" X 7'- 4" square base.

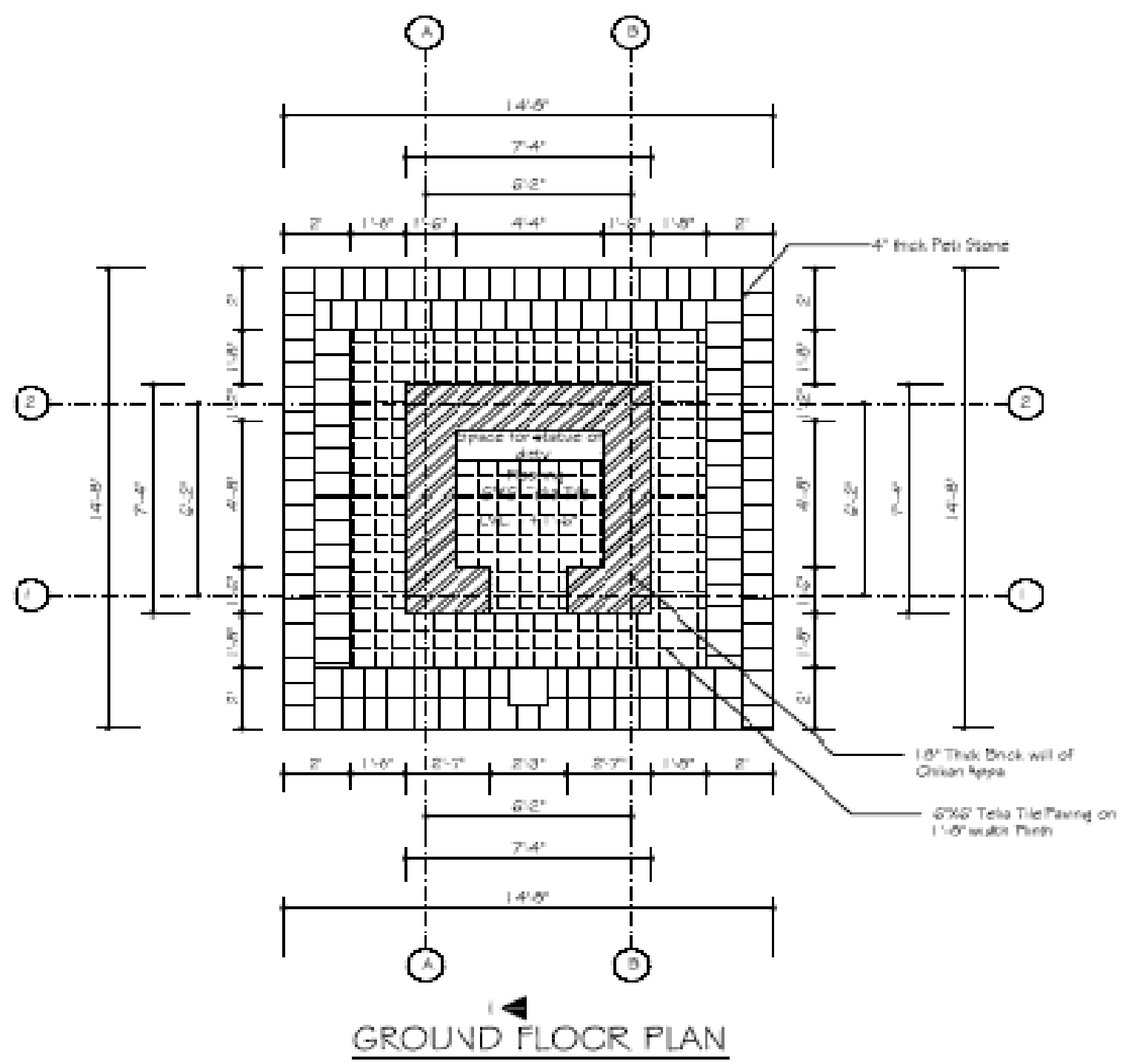

Fig 2 Plan of Manju Shree Degah 


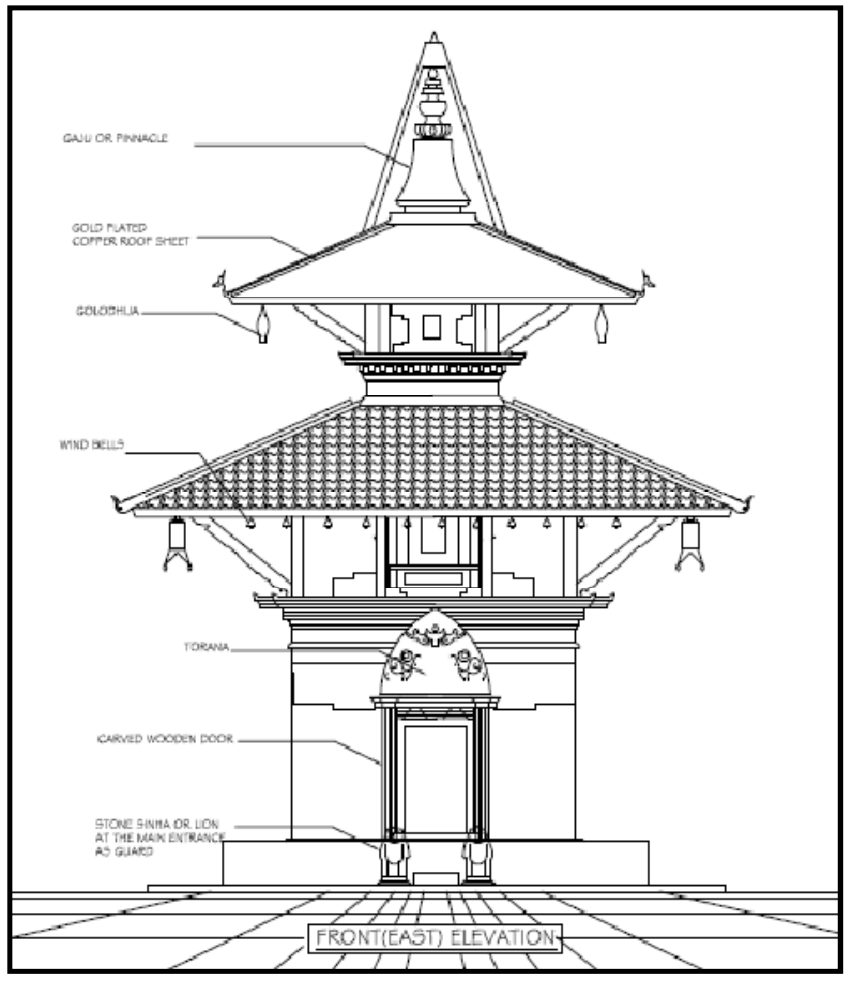

Fig 3 Front elevation of Manju Shree Degah

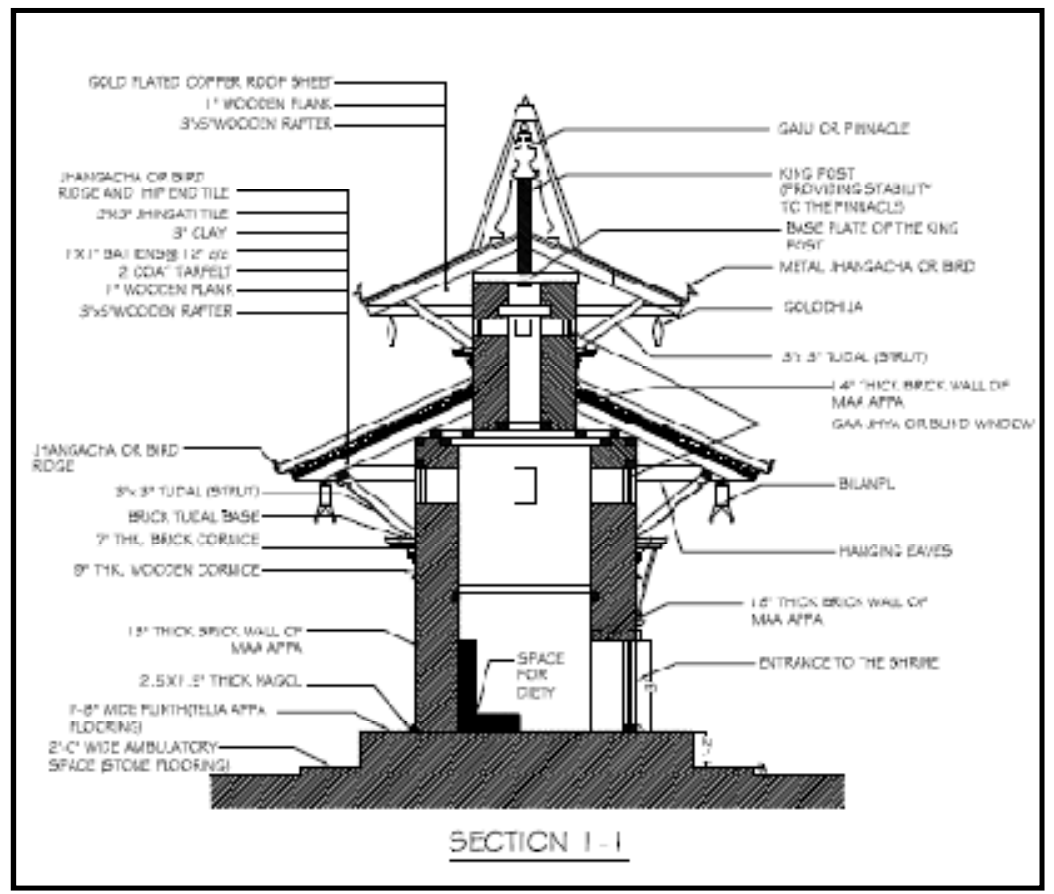

Fig 4 Section of Manju Shree Degah 


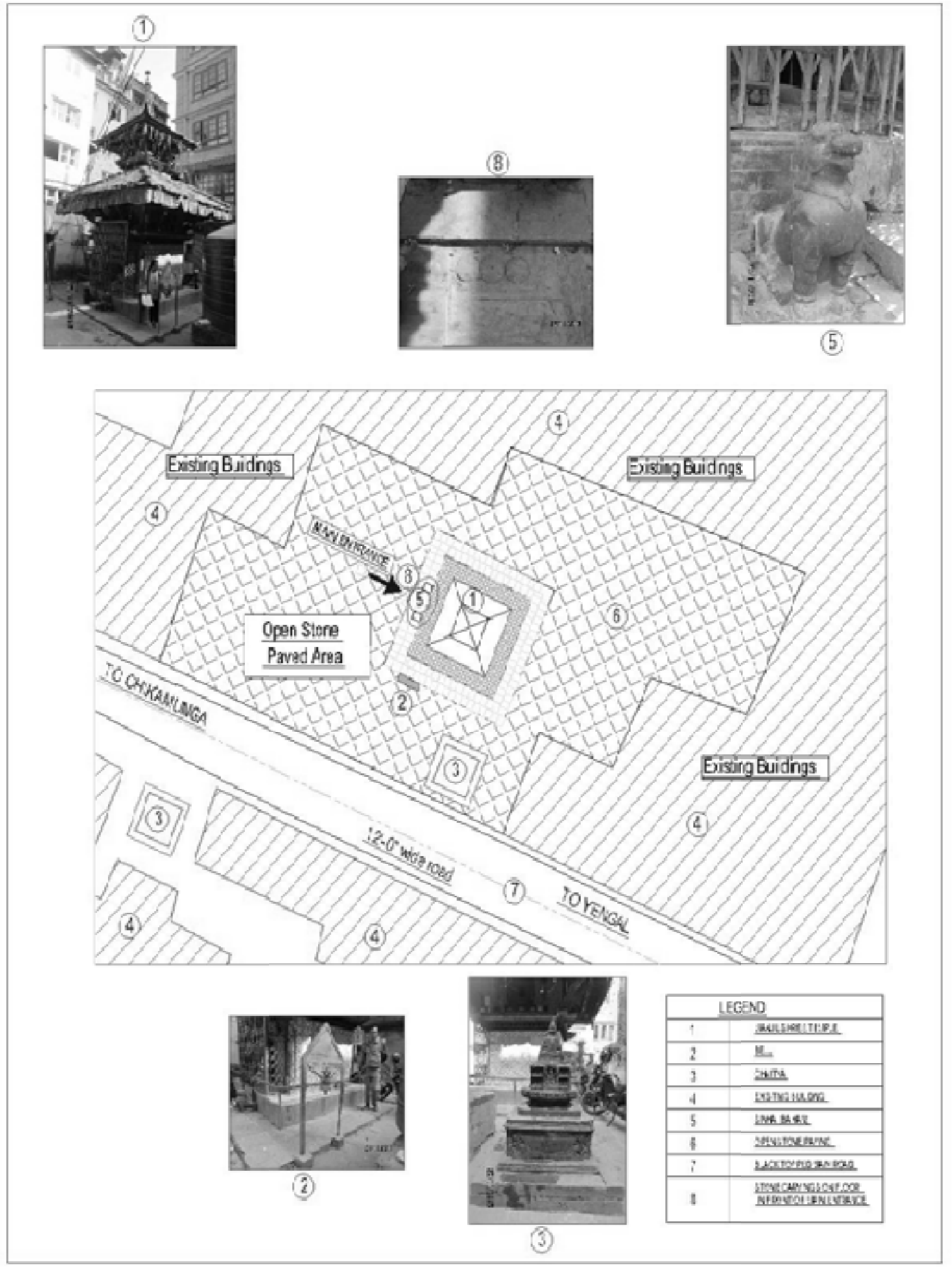

Fig 5 Master Plan of Manju Shree Degah

\section{Restoration}

The degah was restored many times by devotees. But due to the lack of proper knowledge and sufficient fund, the degah lost its original beauty. In order to preserve the historically and 
archeologically important degah, a step has been made by the local people and the concerned authority. It was restored at 2074 B.S.

\section{- Comparision of the condition of degah before and after restoration}

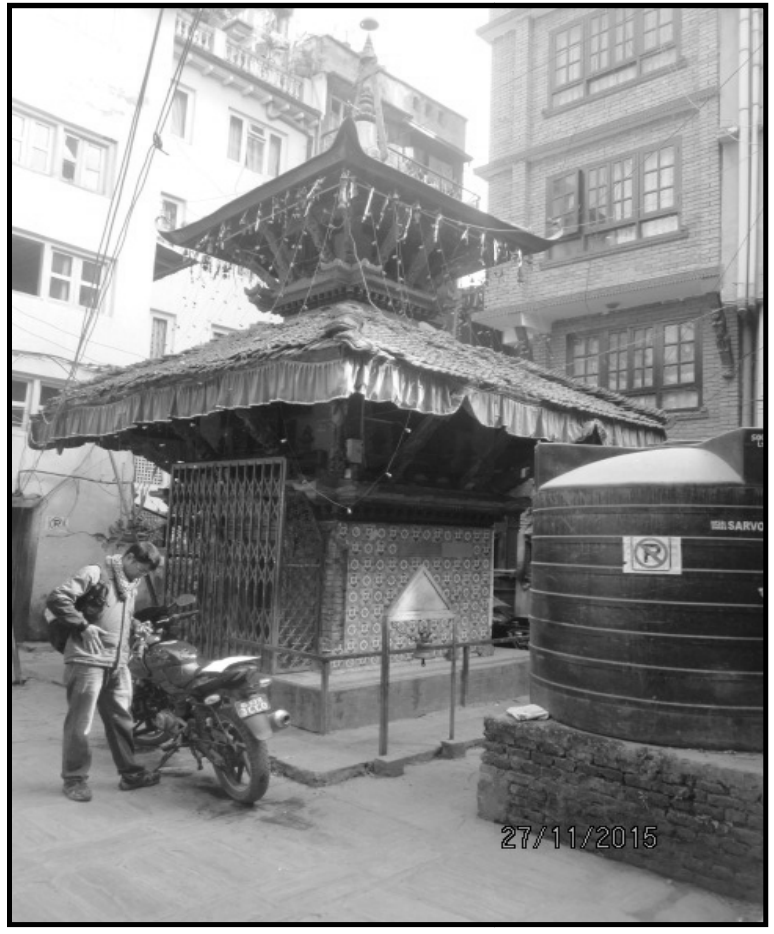

Fig 6 Before restoration

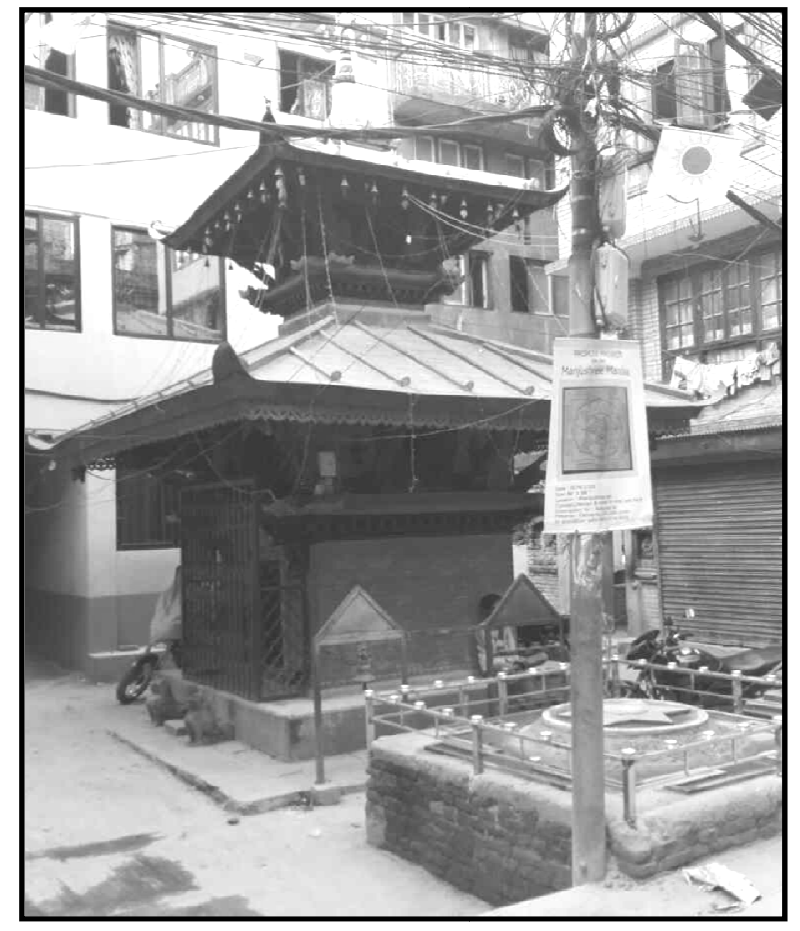

Fig 7 After restoration

\section{Wall of degah}

Before restoration, wall of the degah was clad with modern tiles, which has to be exposed traditional brick wall. According to the inscription, tiles were clad on 1993 B.S after earthquake of 1990 B.S by devotees.

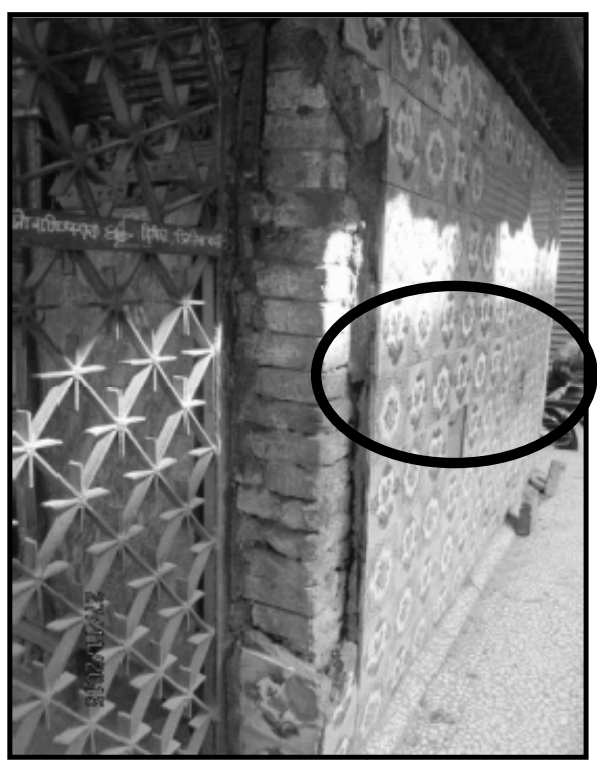

Fig 8 Before restoration

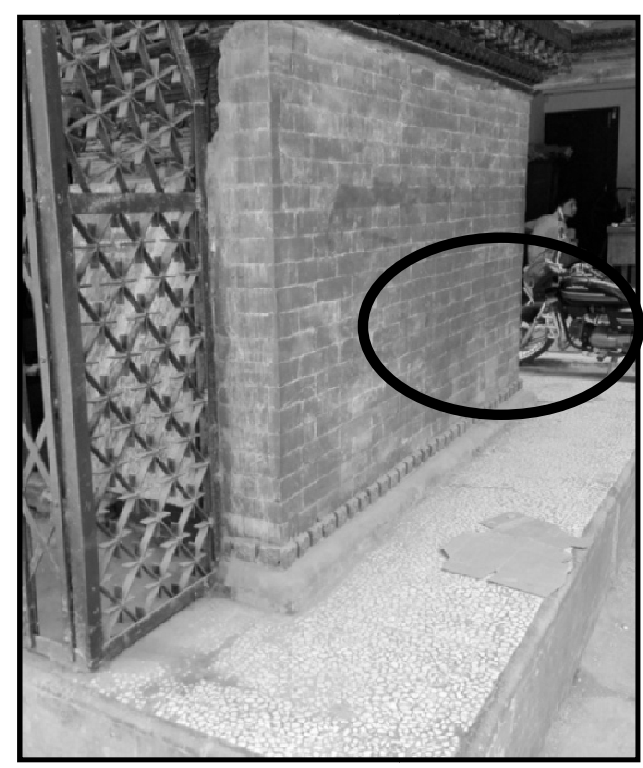

Fig 9 After restoration 
After restoration tiles clad on walls are removed and walls are exposed to bricks walls.

\section{Roof of degah}

This pagoda style temple was two tiered with jhingati roofing on lower roof and gold plated copper sheeting on upper roof.

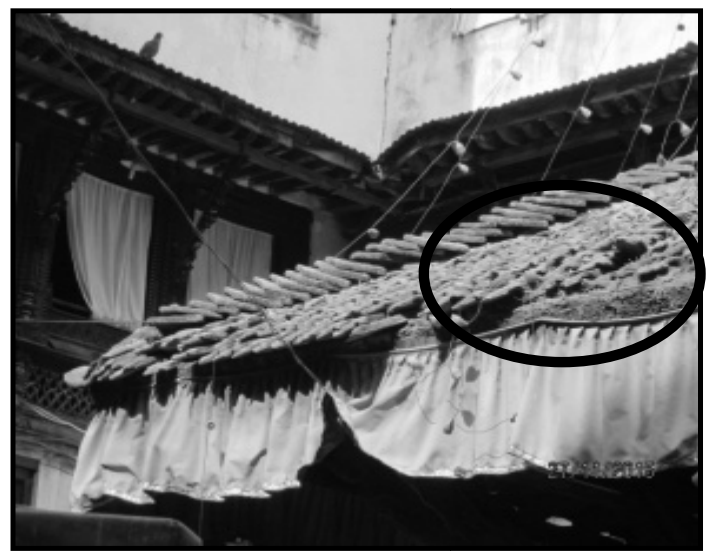

Fig 10 Before restoration

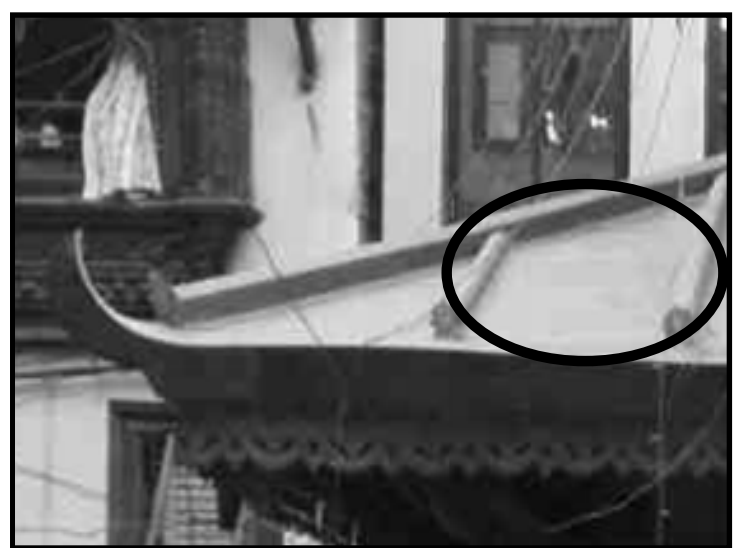

Fig 11 After restoration

After restoration, jhingati ties on lower roof has also been changed to gold plated copper sheeting.

\section{Struts of degah}

Struts are the very important elements of the temple architecture. But before restoration, struts were in dilapidated condition. Some were stolen and some were changed.

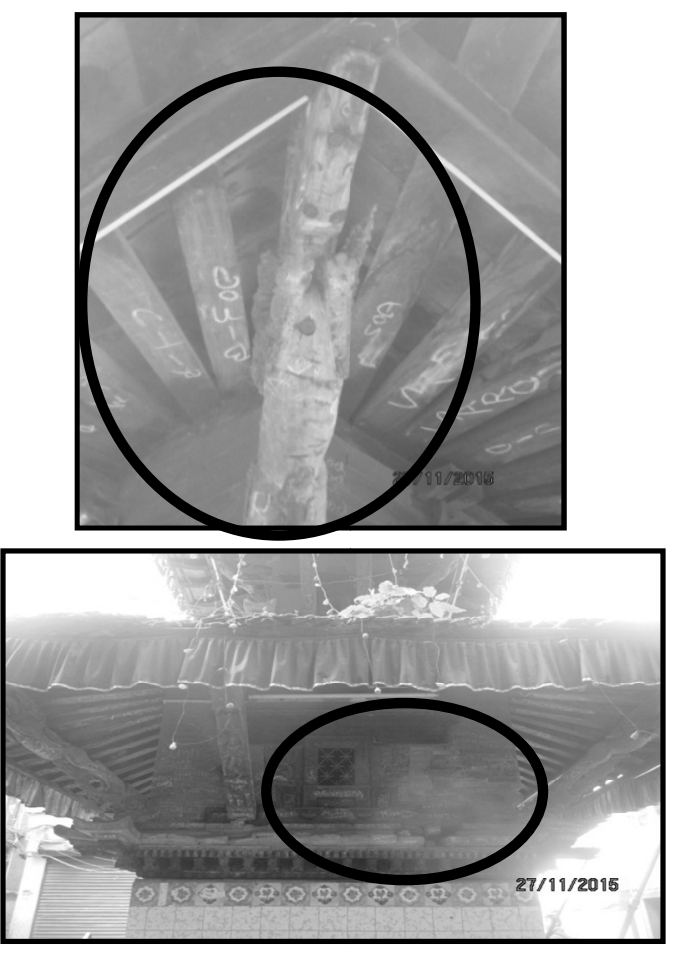

Fig 12 Before restoration

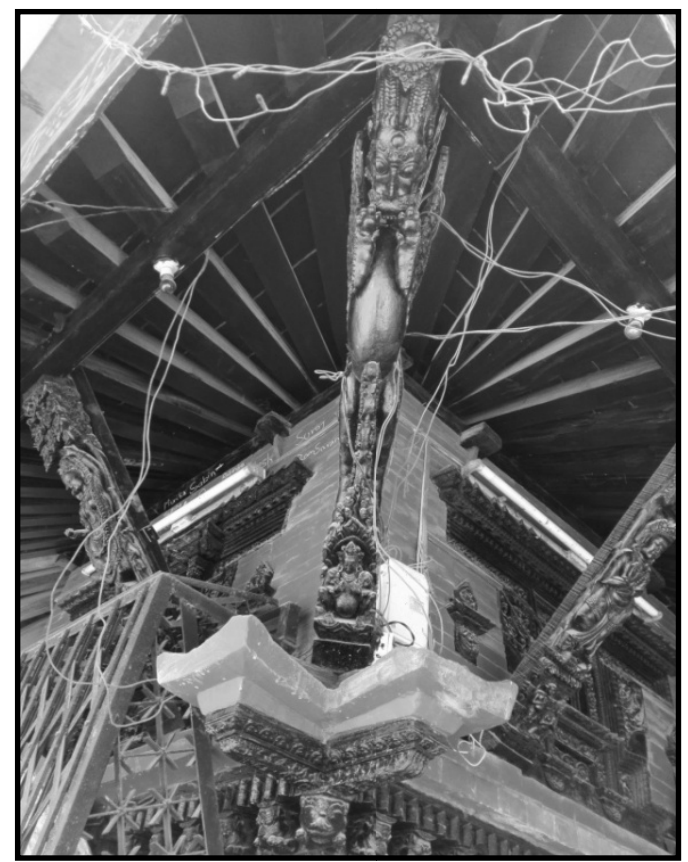

Fig 13 After restoration

After restoration struts are also replaced to its original state. 


\section{Metal diyos of degah}

Many Metal Diyos were stolen.

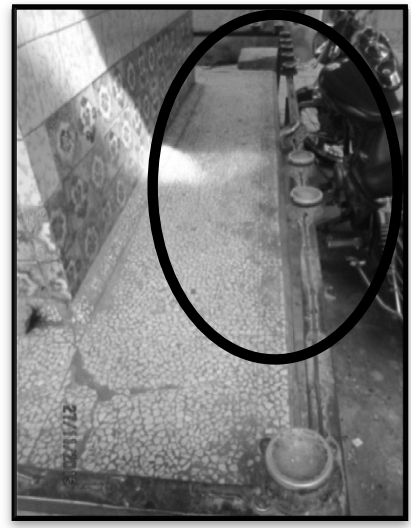

Fig 14 Before restoration

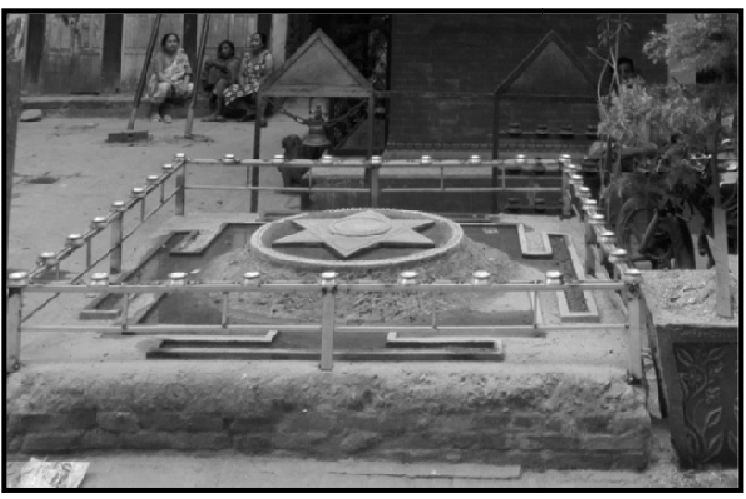

Fig 15 After restoration

New diyo stands were added after renovation.

\section{Disturbing factors}

Location of water tank near the main temple along the side of road was disturbing the view of degah.

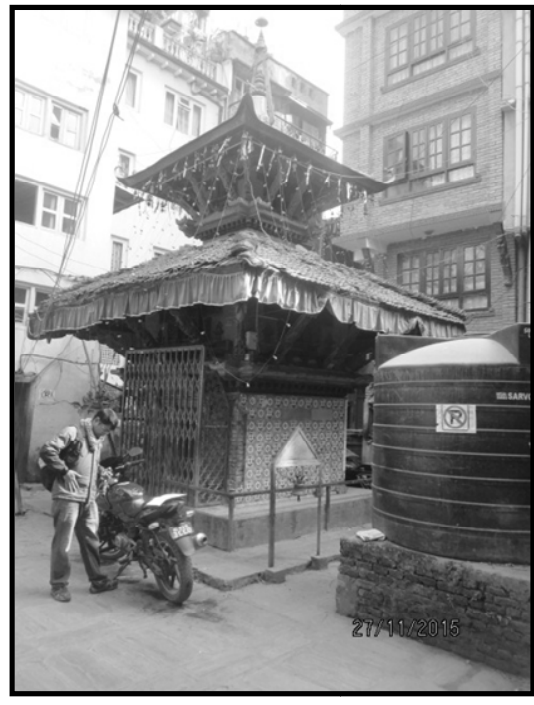

Fig 16 Before restoration

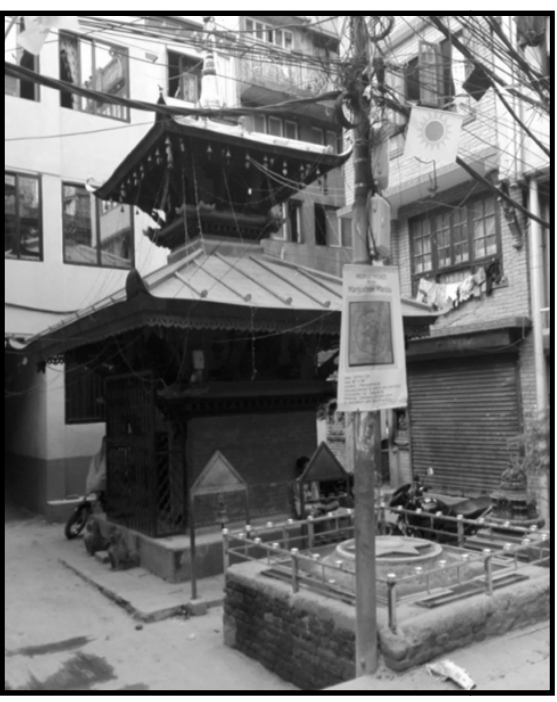

Fig 17 After restoration

New "mandala" is made in the location of water tank. It is complimenting the degah also.

\section{Conclusion}

Historical architecture is precious national assets. All the concerned authorities and local community should take a step to restore these assets. Moreover, it is extremely important to examine traditional building techniques and construction methods that were employed to restore its originality.

\section{References}

1. Korn, W., "The Traditional Architecture of Kathmandu Valley", first edition reprint, 1993.

2. Anagarika Sadachari "Timila". Personal interview, (2015, 20 Nov).

3. Bajracharya, "Roop Skandha Muni”. Personal interview, (2015,27 Nov).

4. Ranjit, Himal, "Manjushree Pucha”, Personal interview, (2015,7 Oct). 